\title{
At the Discourse-Myth interface: A Corpus- based Analysis of Mourning Becomes Electra
}

\begin{abstract}
Nagwa Younis
Ain Shams University

Abstract

The Electra-myth as a dramatic theme has an outstanding expressive capacity. The aim of this paper is to scrutinize the interplay between myth and discourse in O'Neill's trilogy Mourning Becomes Electra. In so doing, Corpus Linguistics is the research method adopted in this study. Keyword in Context (KWIC), frequency and collocation are three techniques provided by the software AntConc 3.5.7 (Anthony, 2018) and applied for data analysis. The interrelationships among characters, which are verbally portrayed as a linguistic manifestation of the Greek myth in discourse, are depicted through these tools. The untypical mother-daughter relationship has its atypical father-daughter/ mother-son counterparts that portray a tragic atmosphere shadowed by the gloomy scent of the Electra-myth. Discursive practices serve as linguistic realizations that bridge the gap between the mythical and the real. Results highlight the effective role played by corpusbased studies to underpin modern discourse analysis.
\end{abstract}

Keywords: Corpus Linguistics, Discourse Analysis, KWIC, Frequency, Collocation

العدد الرابع والعشرون (الجزء الرابع) 2018

مجلة كلية التربية- جامعة عين شمس15 


\section{على محك الخطاب والأسطورة: تحليل يستند إلى علم لغة المتون لثلاثية الحداد يليق بإليكترا \\ نجوى يونس}

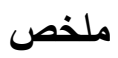

تتميز أسطورة اليكترا كموضوع درامي بقدرة تعبيرية خاصة. تهدف هذه الورقة إلى

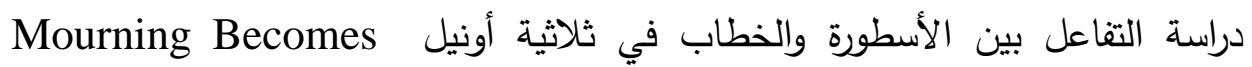

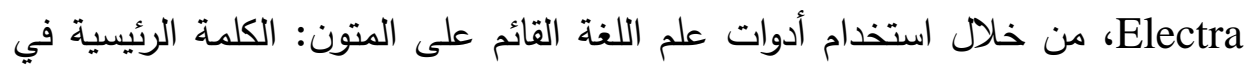
السياق (KWIC) ، ومعدل التكرار والمتصاحبات اللغوية وهي ثلاثة تقنيات يوفرها البرنامج AntConc 3.5.7) وتطبيقها على تحليل البيانات. إن وصف العلاقات بين الثخصيات ، والتي يتم تصويرها لفظيا باعتبارها مظهرا لغويا

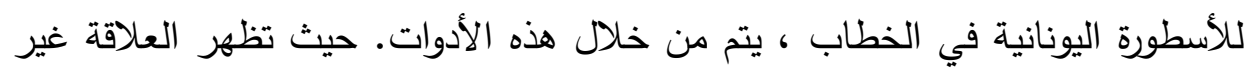

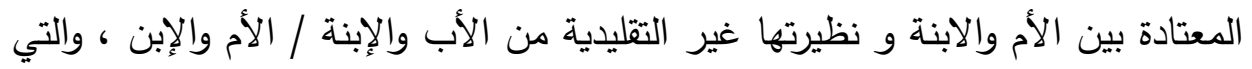

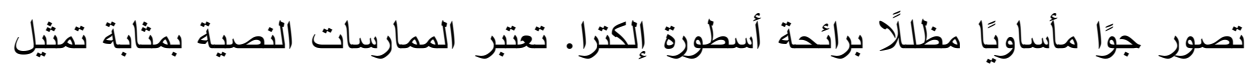
لغوي يجسر الفجوة بين الأسطورية والواقعية. تسلط النتائج الضوء على الدور الفعال الذي تلعبه الدراسات القائمة على المتون في دعم التحليل الحديث للخطاب. 


\title{
At the Discourse-Myth interface: A Corpus- based Analysis of Mourning Becomes Electra
}

\section{Introduction}

\author{
Nagwa Younis \\ Ain Shams University
}

Between what is mythical and what is real, there lies lots of discursive practices. Ancient Greeks thought of myth as an "assertive discourse of power and authority that represents itself as something to be believed and obeyed" (Lincoln, 1999, p.17). Myth, according to Roland Barthes, "is a type of speech"; it is "a system of communication," "a mode of signification" but one to which we must "assign ... historical limits, conditions of use," and to which we must "reintroduce society." "It is not," he adds, "defined by the object of its message, but by the way it utters this message [for] myth is a type of speech" (Barthes, 1972, p. 109, emphasis in the original). Terry Eagleton (1991) argues that people in positions of power use myth as a rhetorically persuasive device: that power in and of itself fosters beliefs and practices that then become standardized. In like manner, this is what Cassirer (1946, p. 14-15) refers to as ' $[t]$ his insight into the determining and discriminating function, which myth as well as language performs in the mental construction of our world of "things". This contradicts the view of Max Müller that "Mythology, which was the bane of the ancient world, is in truth a disease of language' (Müller 1885, p. 12).

Interweaving the structure of myth, language and music is pivotal in the thought of some philosophers of language such as Lévi-Strauss (1955). He holds the view that mythological worlds have been built up only to be shattered again, and that new worlds were built from the fragment. Lévi-Strauss (1955, p. 435) defines the myth as 'consisting of all its versions'. For him, 'a myth remains the same as long as it is felt as such'. The Freudian use of
العدد الرابع والعشرون (الجزء الرابع) 2018
()
مجلة كلية التربية- جامعة عين شمس17 
At the Discourse-Myth interface: A Corpus-based Analysis of Mourning

Becomes Electra

the Oedipus myth is the example Lévi-Strauss offers to prove his point.

This paper purports to speculate the linguistic interrelationships that mingle discourse with myth. O'Neill's trilogy Mourning Becomes Electra is based on a well-known Greek myth, and the playwright asserts the obvious similarity. The legend of Electra, the devoted daughter whose only goal in life was to avenge her father's cruel homicide on his murderers - her mother Clytemnestra and the latter's paramour - and who succeeded in doing so with the aid of her brother Orestes, has fascinated many writers from antiquity to the present day and provided them with a literary subject.

Mourning Becomes Electra, in particular, has the privilege of being one of the most important works in the repertoire of O'Neill. It was in his maturational stage that the Nobel Prize owner wrote this play. Thus, it reveals many characteristics of his discourse. The trilogy is divided into three parts, each having its own title: Homecoming, The Hunted, and The Haunted. Designed as a trilogy, this allows for the precise and extensive analysis of the theme(s) of the play throughout character development and the evaluation of events through a considerable amount of interaction. This also allows for the accurate investigation of the relationship between the characters as revealed in the play.

O'Neill has made use of a theatrical device which was the main stylistic characteristic of ancient Greek dramaturgy in general: the element of chorus. In the beginning of each of the three plays O'Neill presents a group of townspeople who comment on the incidents of the previous scene, in the same way the ancient chorus did between the episodes. The first play, 'Homecoming', starts with a group of intruders, secretly brought to the grounds of the Mannon

العدد الرابع والعشرون (الجزء الرابع) 2018

()

مجلة كلية التربية- جامعة عين شمس18 


\section{Nagwa Younis}

residence by Seth, the housekeeper, with whom they are acquainted: 'These last three are types of townsfolk rather than individuals, a chorus representing the town come to look and listen and spy on the rich and exclusive Mannons.' (p.17). It is significant and certainly points to Greek drama that it is through this chorus that the Mannons, the protagonists, are presented to the audience. O'Neill may also have wanted to emphasize the similarity to Greek drama as he himself refers to the group of townspeople as chorus. Similarly, in the beginning of 'The Hunted', a group of people returning from Ezra Mannon's funeral, give us information about the state Christine Mannon is in before we actually see her:

These people - the Bardens, Hills and his wife and Doctor Blake - are as

were the Ames of Act One of 'Homecoming', types of townfolk, a chorus representing as those others had, but in a different stratum of society, the town as a human background for the drama of the Mannons. (p.117)

The following questions are attempted to be answered in this paper:

1. How do discursive practices give the spell of 'myth' in Mourning Becomes Electra?

2. How are characters interactions linguistically portrayed to serve both the mythical and the real?

3. To what extent a corpus-based analysis helps reveal the discourse-myth interface?

The design of the paper goes in the following fashion: $\S 2$ is a background in which Mourning Becomes Electra is introduced as a discursive exploitation of Greek mythology. In $\S 3$, the research method is explained, and corpus-based tools are presented. The analysis of data as well as the results are discussed in $\S 4$. Concluding remarks and suggestions for further research are summarized in $\S 5$.

العدد الرابع والعشرون (الجزء الرابع) 2018

مجلة كلية التربية- جامعة عين شمس 19 


\section{Background}

The study tackles the linguistic manifestation of myth in discourse from a corpus perspective. Discourse analysis in general has typically been a qualitative endeavor, with studies focusing on only a few texts. In contrast, a corpus-based approach requires analysis of a well-designed 'representative' collection of texts of a particular genre. Being encoded electronically, these texts allow for more complex and generalizable research findings, revealing linguistic patterns and frequency information that would otherwise be too labour intensive to uncover by hand (Baker, 2008). Corpusbased discourse analysis depends on both quantitative and qualitative techniques. Even with a corpus-based approach, one or more linguistic type in each text is first identified and tagged individually by the researchers making qualitative judgments about the communicative purposes of the different parts of a text; and even once quantitative data are run, the results must still be interpreted functionally. 'Association patterns represent quantitative relations, measuring the extent to which features and variants are associated with contextual factors. However, functional [qualitative] interpretation is also an essential step in any corpusbased analysis' (Biber et al., 1998: 4). Three corpus-based tools are utilized in this study through applying AntConc 3.5.7 (Anthony, 2018): Keyword in Context (KWIC), Frequency, and Collocation.

\subsection{Keyword in Context (KWIC)}

In A Glossary of Corpus Linguistics (2006), Baker et al. define Keyword in Context (KWIC) as "a list of all of the occurrences of a particular search term in a corpus" (pp.42-43). According to Biber (2011), "[k]eyword analysis attempts to identify the individual words that characterize a literary work: words that are statistically more likely to occur in the target corpus than in the comparison corpus"(p.16). Besides Culpeper

العدد الرابع والعشرون (الجزء الرابع) 2018

()

مجلة كلية التربية- جامعة عين شمس20 - م 
(2009) refers to this kind of statistics as it is meant to identify the keywords, and is often combined with a kind of cut-off, to avoid the identification of rarely mentioned words. For Baker et al. (2006), "[k]eywords reveal words which may not be hugely frequent but are definitely statistically salient in some way" (p.3). Keyword analysis is the words that are more frequent within the main corpus when compared to a second corpus, if it exists, which often functions within the study as "reference corpora", and is often dealt with as a representative of "standard language" with the same qualification of the main corpora.

\subsection{Frequency}

Frequency lists within the corpus analysis, as postulated by Flowerdew (2012), is very useful in the "preliminary stages of analysis as they provide a good starting point for more detailed investigation into the grammatical or content words in a text" (p.10). For instance, word frequency lists at the beginning of the analysis of the most frequent 25 words within the main corpus; compared with the least 25 words in a word frequency list reveals the main theme and the priorities of the main corpus writer. At this point, Flowerdew (2012) emphasizes the importance of the size of the corpus to generate frequency data. He suggests that within long texts about half of the words will occur once. Consequently, to reach valid results, "then a corpus needs to contain many million words in order to generate a sufficient number of occurrences of the different uses on which to base descriptive statements."(pp. 10-11).

From the viewpoint of Baker et al. (2006), frequency is one of the most central concepts underpinning the analysis of corpora. However, its importance to this field of research has resulted in one of the most oft-heard misconceptions of corpus linguistics - that it is 'only' a quantitative

العدد الرابع والعشرون (الجزء الرابع) 2018

()

مجلة كلية التربية- جامعة عين شمس21 
methodology, leading to a list of objections: frequencies can be reductive and generalizing, they can oversimplify and their focus on comparing differences can obscure more interesting interpretations of data. (p.47) it is postulated that language is a list of choices. Stubbs (1996) holds the view that, concerning the choice of words, "[n]o terms are neutral. Choice of words expresses an ideological position"(p.107). There is a tension between two points of view, which is very abundant in analyzing literature. This means that when writers always use one word over another, this reveals intentions and views and typically defines the kind of writing. This also shows the importance of having lexical analysis for the most frequent words, in which the importance of denotation and connotation is clear.

\subsection{Collocation}

Baker (2006) refers to the notion of collocations as, "[a]11 words co-occur with each other to some degree. However, when a word regularly appears near another word, and the relationship is statistically significant in some way, then such co-occurrences are referred to as collocates and the phenomenon of certain words frequently occurring next to or near each other is collocation. "(p.95). Similarly, Stubbs (1996) comments on the idea of collocations saying, "Words occur in characteristic collocations, which show the association and connotations they have, and therefore the assumptions they embody" (p.172).

Collocations, therefore, indicate a relationship in one way or another, but within the actual work of the analysis. Through corpus analysis, concordance has to be carried out first in order to identify how the relationship of words is identified and manifested in a language. Baker (2010), then, refers to a

2018 العدد الرابع والعشرون (الجزء الرابع)

()

مجلة كلية التربية- جامعة عين شمس22 
condition that has to be clarified in the mind of the researcher through the analysis, which is "If two words collocate, then they have a tendency to occur near or next to each other in naturally occurring language use" (p.24).

Collocation is viewed as a tool provided by the AntConc 3.5.7 software to facilitate the analysis. "Collocation", according to Biber (2011), means "the way in which particular words are associated with each other, as shown empirically by their tendency to co-occur more frequently than would be expected by chance' (p.18). Baker and McEnery (2015) offer a full definition identifying the term collocation pointing that "Collocation involves the identification of words which tend to occur near or next to each other a great deal, much more than would be expected if all the words in a corpus were ordered in a random jumble" (p. 3).

The concept 'semantic prosody' is a rather recent concept that ascribes its parentage to corpus linguistics and its fatherhood to John Sinclair in the University of Birmingham. It refers to the shades of meaning or semantic aura related to the choice of a certain lexical item rather than another (Louw, 1993, Sinclair, 1996, Stubbs, 1996, Partington, 1998, Hunston and Francis, 2000). It reflects the Firthian tradition that lexical items are habitually associated with particular connotations.

\section{Research Method}

The researcher adopts both the quantitative and the qualitative methods to corpus studies to scrutinize the discourse-myth interplay in Mourning Becomes Electra. Electronically stored, the original script is downloaded from Project Gutenberg (www.gutenberg.org) in a plain text format.

العدد الرابع والعشرون (الجزء الرابع) 2018

()

مجلة كلية التربية- جامعة عين شمس 23 
At the Discourse-Myth interface: A Corpus-based Analysis of Mourning

Becomes Electra

Antconc 3.5.7 (Anthony, 2018) is the concordancing tool used for generating $K W I C$ (key word in context), frequency and collocation. Keyness is examined against COCA (Corpus of Contemporary American) as a reference corpus.

These three techniques are applied to four types of interaction, reflecting the relationships between the main characters. These interactions can be subsumed under the following headings:
a. mother-daughter interaction
b. husband-wife interaction
c. mother-son interaction
d. father-daughter interaction

\section{Results and Discussion}

Under the umbrella tenets of Corpus Linguistics, the interrelation between discourse and myth is depicted through the tools: Keyword in context (KWIC), depicted through the tools: Keyword in context (KWIC), Frequency, and Collocation.

\subsection{KWIC}

Key word in context (KWIC) is a corpus-based technique which identifies important words, or most frequently used words, in a given corpus as compared against a benchmark corpus. By using specific statistics for keyword analysis, a number of keywords that tend to occur more frequently in a target corpus when compared with its relative frequency in a reference corpus (Scott, 2010; Scott \& Tribble, 2006) can be automatically identified. Keyness in Mourning Becomes Electra is examined against the backcloth of the reference corpus COCA (Corpus of
2018
العدد الرابع والعشرون (الجزء الرابع)
()
مجلة كلية التربية- جامعة عين شثس24 
Contemporary American), and automatically generated using Antconc 3.4.

'Keyness' is a matter of being statistically unusual relative to some norm (Culpeper 2009, p.34). In the generated table of keyness in Mourning Becomes Electra, it is observed that keywords here relate to the text's 'aboutness'. 'Lavinia', 'Orin' and 'Christine' are the most key words in the text. The relationship among characters, especially these three, is the 'key' or the clue to the general theme of the play. The pronoun 'you' is also significant as it indicates the accusing tone prevailing all through the play.

The interactions among family members are analysed regarding the relationship among characters. Four types of interactions are detected and observed in the light of Table 1.

Table 1: Keyness in Mourning Becomes Electra

\begin{tabular}{|c|c|c|c|c|c|}
\hline \multicolumn{6}{|c|}{ 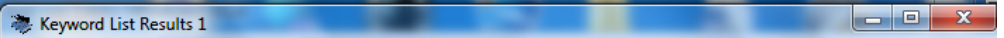 } \\
\hline $\begin{array}{l}\text { Types B } \\
\text { Rank }\end{array}$ & Types Before Cut: 4450 & $\begin{array}{l}4450 \\
\text { Keyness (LL) }\end{array}$ & $\begin{array}{l}\text { Types After Cut: } 3329 \\
\text { Keyword }\end{array}$ & Search Hits: 0 & \\
\hline 1 & 530 & 3589.714 & lavinia & & \\
\hline 2 & 487 & 3298.473 & orin & & \\
\hline 3 & 1943 & 2513.178 & you & & \\
\hline 4 & 366 & 2387.351 & christine & & \\
\hline 5 & 204 & 1359.320 & hazel & & \\
\hline 6 & 192 & 1300.425 & mannon & & \\
\hline 7 & 243 & 1271.133 & don & & \\
\hline 8 & 176 & 1192.056 & brant & & \\
\hline 9 & 174 & 1178.510 & vinnie & & \\
\hline 10 & 896 & 1145.188 & her & & \\
\hline 11 & 230 & 1032.315 & peter & & \\
\hline 12 & 1749 & 996.393 & i & & \\
\hline 13 & 153 & 878.631 & seth & & \\
\hline 14 & 556 & 742.030 & me & & \\
\hline 15 & 512 & 732.367 & him & & \\
\hline 16 & 795 & 686.792 & t & & \\
\hline 17 & 647 & 497.133 & she & & \\
\hline 18 & 367 & 493.131 & then & & \\
\hline 19 & 69 & 442.605 & ezra & & \\
\hline
\end{tabular}

العدد الرابع والعشرون (الجزء الرابع) 2018

()

مجلة كلية التربية- جامعة عين شمس25 
At the Discourse-Myth interface: A Corpus-based Analysis of Mourning

Becomes Electra

\section{1.a. Mother-daughter interaction}

The interaction between Christine and Lavinia, her daughter, is characterized by a significant use of challenging moves by the two participants. Features of typical mother-daughter discourse, such as agreement, compliments, and obedience do not occur. On the contrary, power asymmetry is reversed where the daughter assumes a higher conversational role than the mother. This is signified in a range of linguistic forms, such as the recurrent use of challenging moves and acts of accusation which are current in Christine-Lavinia discourse. In addition, there is a clear lack of conversational support as revealed by the continuous reciprocal acts of accusation throughout the interaction in the whole play.

Most of the interaction is dominated by the daughter and not by the mother. Lavinia is a conversant who initiates the exchanges, who speaks first and who speaks most. She is the dominant participant. Lavinia uses rhetorical questions (e.g. 'has it been hard for you?') and deprives her mother of her turn by providing a comment immediately after posing the question (e.g. 'I'd never guess it').

\section{1.b. Husband-wife interaction}

This type of interaction asserts the alienation that Ezra Mannon feels at home. It denotes also the dominance of Christine over her husband. This is articulated in her challenges with her husband which are characterized by challenging moves, acts of elicitation and directives. When Christine threatens Ezra that she will leave him, he does not hesitate to apologize. Nevertheless, she does not pay his apology any attention. Christine uses warnings in her interaction with her husband. She says to him:

العدد الرابع والعشرون (الجزء الرابع) 2018

مجلة كلية التربية- جامعة عين شمس 
- Ezra, if you are going to say stupid things, I'll go in my own room. (p. 100)

In the following interaction we find that more acts of elicitation are made by Ezra while Christine only replies with short sentences. This happens during Christine's deep thinking to kill Ezra. Her mind is occupied with the idea of getting rid of him so she is not an active participant during their conversation. She just keeps the passive side. This indicates her evasive and cunning character.

\section{1.c. Mother-son interaction}

The relationship between Orin and his mother Christine is typically a mother-son relationship. Their interactions usually have the characteristic that Orin usually supports his mother's moves. Even when he attempts some elicitation acts, they are only out of jealousy. One gets the impression that Orin suffers from Oedipus Complex. He kills his mother's lover because he thought that she 'betrayed' him. Most interactions illustrate how Orin is under his mother's thumb even though he has become a grown-up person.

Orin tries to express his deep love and jealousy to his mother. The mother tries to gain the son to her side. She easily persuades him that he is her only baby to make him forget all about Adam Brant, her lover. Orin's moves turn out very soon to be all supports of his mother's. It's Christine, the mother, who has power and dominance over her son. The son also madly loves his mother to the extent that he kills Adam Brant. When his mother commits suicide as a result, he also kills himself after suffering madness.

العدد الرابع والعشرون (الجزء الرابع) 2018

مجلة كلية التربية- جامعة عين شمس 
At the Discourse-Myth interface: A Corpus-based Analysis of Mourning

Becomes Electra

\section{1.d. Father-daughter interaction}

The relationship between Lavinia and her father, Ezra Mannon, is the same as that between Orin and his mother, Christine. Lavinia loves her father madly and she is jealous of her mother. She seems to suffer from Electra Complex, hence the title of the play. The interactions between Lavinia and her father are a few because Mannon is killed at the end of Part One of the trilogy. He appears only in two scenes in the play. However, the following interaction shows how far Lavinia's exchange structure with her father expresses her excessive love and blind obedience.

\subsection{Frequency}

The linguistic preference of choosing more lexical items than others in discourse reveals a lot about the author's world view. Since the Electra-myth is highly manifested in this trilogy through the family interrelationships, frequency is best examined in terms that insinuate or suggest the distribution of power among characters. Terms of address have an interpretive power in the analysis of interactions in dramatic discourse. They signify dominance, intimacy, solidarity, power, formality and politeness. According to a number of sociolinguists (Murphy 2010), mutual first name indicates equality and familiarity, whereas the use of first name without reciprocity is a heavy marker of power. 'Terms of address' in Mourning Becomes Electra is a technique that can be used effectively to indicate different relationships within the same family.

العدد الرابع والعشرون (الجزء الرابع) 2018

()

مجلة كلية التربية- جامعة عين شمس28 
Nagwa Younis

\begin{tabular}{llll}
\hline \multicolumn{5}{c}{ Table 2: Frequency of Address Terms in Mourning Becomes } \\
Electra \\
\hline $\begin{array}{l}\text { Address } \\
\text { Term }\end{array}$ & Homecoming & $\begin{array}{l}\text { The } \\
\text { Hunted }\end{array}$ & $\begin{array}{l}\text { The } \\
\text { Haunted }\end{array}$ \\
\hline Ezra & 37 & 23 & 8 \\
\hline Christine & 53 & 36 & 0 \\
\hline Lavinia & 47 & 50 & 30 \\
Orin & 25 & 123 & 95 \\
Vinnie & 49 & 57 & 67 \\
\hline Father & 57 & 32 & 8 \\
\hline Mother & 9 & 49 & 30 \\
Dear & 1 & 10 & 2 \\
Darling & 0 & 1 & 0 \\
My boy & 0 & 2 & 0 \\
\hline My baby & 0 & 2 & 0 \\
Young & 2 & 0 & 0 \\
lady & & & \\
\hline
\end{tabular}

\section{Concordance hits of address terms in each part of Mourning} Becomes Electra by AntConc 3.4.4

Concerning the aspects of terms of address, the analysis of the play is divided into four types of interaction, representing the different character-relationships in the play. The data are semiautomatically filtered so that figures match each section.

$$
\begin{aligned}
& \text { العدد الرابع والعشرون (الجزء الرابع) } 2018 \\
& \text { مجلة كلية التربية- جامعة عين شمس29 }
\end{aligned}
$$


At the Discourse-Myth interface: A Corpus-based Analysis of Mourning Becomes Electra

Table 3: Relation between type of interaction and frequency in Mourning Becomes Electra (divided by parts)

\begin{tabular}{|c|c|c|c|c|c|c|}
\hline $\begin{array}{l}\text { Interactio } \\
\mathrm{n}\end{array}$ & \multicolumn{2}{|l|}{ Homecoming } & \multicolumn{2}{|l|}{ The Hunted } & \multicolumn{2}{|c|}{ The Haunted } \\
\hline \multirow{6}{*}{$\begin{array}{l}\text { Mother- } \\
\text { daughter }\end{array}$} & Vinnie & 3 & Vinnie & 58 & Vinnie & 67 \\
\hline & \multirow{2}{*}{$\begin{array}{l}\text { Mothe } \\
r\end{array}$} & \multirow[t]{2}{*}{1} & Mother & 34 & Mother & 47 \\
\hline & & & Lavinia & 50 & Lavinia & 29 \\
\hline & Lavini & \multirow[t]{2}{*}{ - } & Dear & 6 & \multirow{2}{*}{ Dear } & \multirow{2}{*}{3} \\
\hline & $\mathrm{a}$ & & & & & \\
\hline & Dear & - & & & & \\
\hline \multirow[t]{3}{*}{$\begin{array}{l}\text { Husband- } \\
\text { wife }\end{array}$} & Ezra & 9 & \multirow{3}{*}{------ } & & \multirow{3}{*}{----- } & \\
\hline & Christine & 13 & & & & \\
\hline & Dear & - & & & & \\
\hline \multirow{5}{*}{$\begin{array}{l}\text { Mother- } \\
\text { son }\end{array}$} & Orin & 25 & Orin & 123 & Orin & 114 \\
\hline & Mother & 58 & Mother & 49 & Mother & 105 \\
\hline & \multirow{2}{*}{$\begin{array}{l}\text { My } \\
\text { boy }\end{array}$} & \multirow[t]{2}{*}{-} & My boy & 3 & My boy & - \\
\hline & & & My baby & 5 & My baby & - \\
\hline & $\begin{array}{l}\text { My } \\
\text { baby }\end{array}$ & 7 & & & & \\
\hline \multirow[t]{4}{*}{$\begin{array}{l}\text { Father- } \\
\text { daughter }\end{array}$} & Vinnie & 49 & \multirow{4}{*}{---.- } & & & \\
\hline & Father & 84 & & & & \\
\hline & Lavinia & 108 & & & & \\
\hline & $\begin{array}{l}\text { Young } \\
\text { lady }\end{array}$ & 2 & & & & \\
\hline
\end{tabular}

\section{2.a. mother-daughter interaction}

Despite the tense relationship and the mutual hatred between Lavinia and her mother, Christine, yet Christine always uses Lavinia's nickname while addressing her. For example:

$$
\begin{aligned}
& \text { العدد الرابع والعشرون (الجزء الرابع) } 2018 \\
& \text { مجلة كلية التربية- جامعة عين شمس30 }
\end{aligned}
$$




\section{Nagwa Younis}

Christine: Do you think I'll give you the satisfaction of seeing me grieve? Oh, no, Vinnie! You'll never have the chance to gloat!

Christine never uses first name when she talks to Lavinia. She also never uses terms of endearment such as 'dear' and 'darling' which she uses frequently when she addresses her son, Orin. The use of the nickname here has the function of trying to be sweet with the enemy.

On the other hand, looking at the terms of address which Lavinia uses to address her mother, we find that she uses the term 'mother' in some exchanges. However, Lavinia uses very abusive and rude words to address her mother. This is unlike the system of address terms usually found in mother/daughter interaction. The following is an example:

Lavinia: Stop lying, I tell you! I went upstairs! I ---------You vile ------! You're shameless and evil! Even if you are my mother, I say it!

Christine: I - I knew you hated me, Vinnie ---- but not as bitterly as that!

(pp. 54-55)

Lavinia refers to her mother as 'shameless' four times, as illustrated in the following screenshot. 
At the Discourse-Myth interface: A Corpus-based Analysis of Mourning Becomes Electra

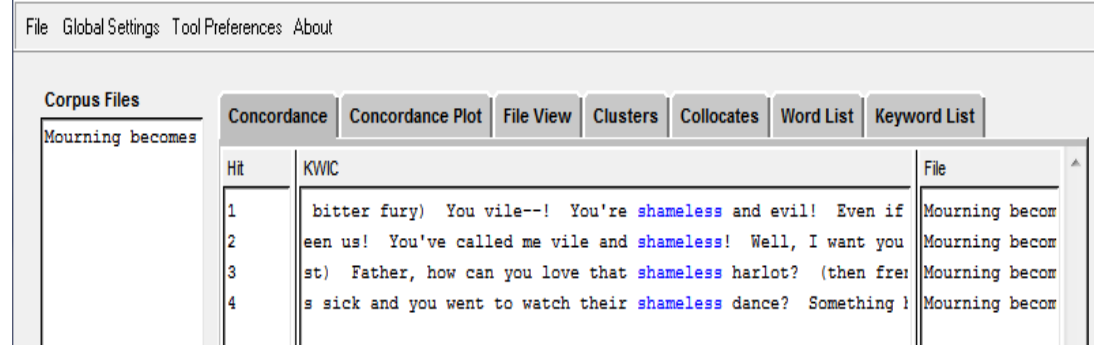

\section{2. b. Husband-wife interaction}

The interaction between Christine and her husband, Ezra Mannon, is characterized by the use of mutual first name. Nevertheless, Christine uses first name more than her husband (69 hits for Ezra, as opposed to. This indicates her dominance over him. Terms of endearment do not appear in the interaction between Christine and Ezra Mannon, which proves the lack of emotion between them, especially on Christine's side:

Mannon: I've dreamed of coming home to you, Christine!

Christine:

I'm

tired,

Ezra.

(p. 90)

Christine: Don't

talk,

Ezra.

(p. 91)

Christine:

Ezra,

please.

(p. 94)

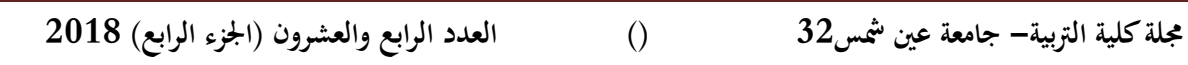




\section{2.c. Mother-son interaction}

Orin is the only person in the family that receives a large number of endearment terms. Christine never addresses neither her daughter, nor her husband by any of these terms. The term 'dear', 'darling', 'my boy' and 'my baby' are used in the play by Christine to address her son, Orin:

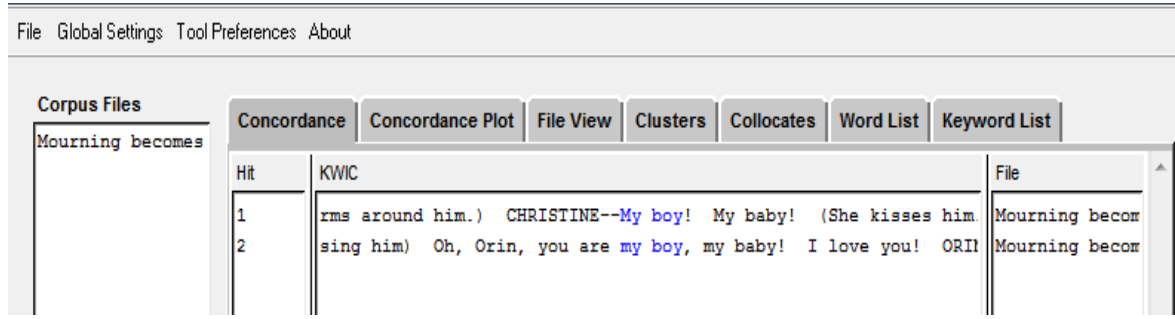

This sheds light on the kind of relationship between Orin and his mother. Throughout the trilogy, there are some hints that Orin suffers from Oedipus complex. The way his mother addresses him and the way she talks to him recalls to our memory the famous novel Sons and Lovers by D. H. Lawrence where the mother treats her sons as her lovers. Examples from the play illustrate this point:

Orin: Mother!

Christine:

My

boy!

My

boy!

(p. 128)

Christine: I? Different? I don't think so, dear.... (p. 128)

(p. 128)

You poor darling, how you must have suffered?

Come on in, dear. It's chilly. Your poor head ------
2018
العدد الرابع والعشرون (الجزء الرابع)
()
جملة كلية التربية- جامعة عين شمس33 
At the Discourse-Myth interface: A Corpus-based Analysis of Mourning Becomes Electra

\author{
Christine: It's just that I'm getting old, I'm afraid, dear. \\ (p. 136) \\ Christine: .... But all I want now is your happiness, \\ dear. (p. 140)
}

Christine: Oh, Orin, you are my boy, my baby! I love you! (p. 147)

Orin: Did you really want me to come back, Mother?

\title{
Christine: What a foolish question, dear.
}

(p. 147)

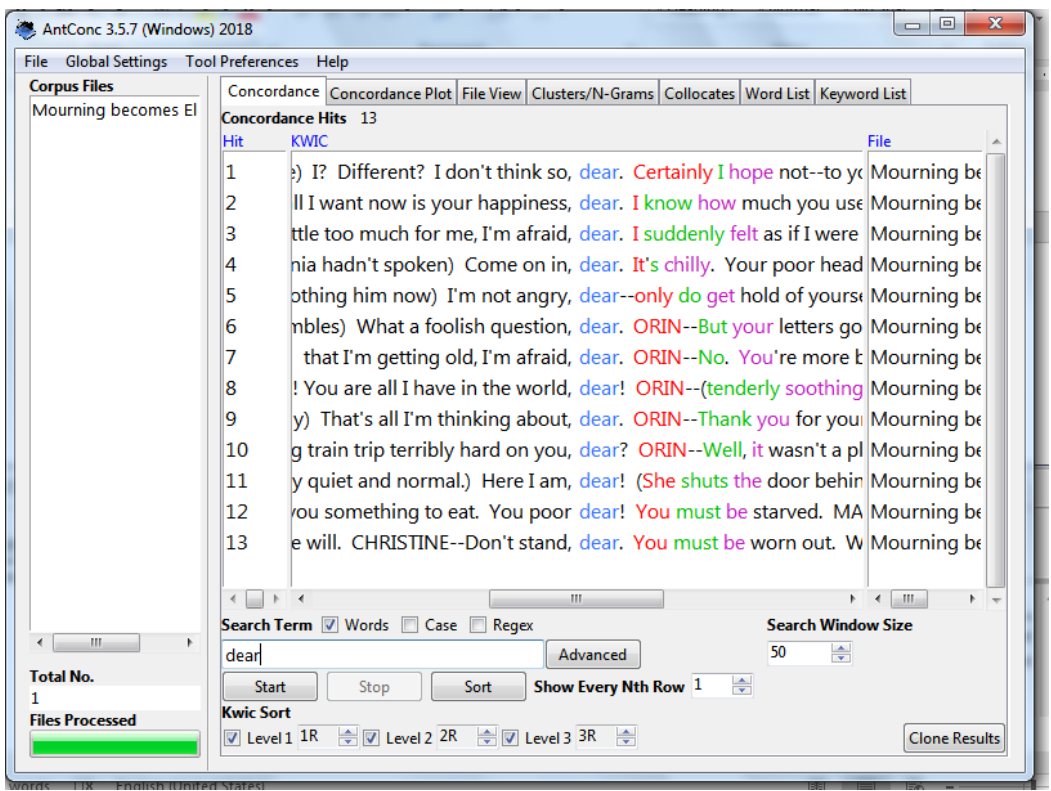

$$
\begin{aligned}
& 2018 \\
& \text { العدد الرابع والعشرون (الجزء الرابع) }
\end{aligned}
$$




\section{Nagwa Younis}

\section{2.d. Father-daughter interaction}

There is mutual love between the father and his daughter as revealed in the terms of address used in their interactions. In spite of the fact that there are very few interactions between Ezra Mannon and his daughter, Lavinia, the terms of address express this. Mannon uses the nickname to address his daughter:

Mannon: It must be your bedtime, Vinnie. (p. 87)

Moreover, the father uses the term 'young lady' to address his daughter:

Mannon: I notice you didn't mention that in your letter, young lady! (p. 86)

This term has only two occurrences by Mannon and is not used by any other character.

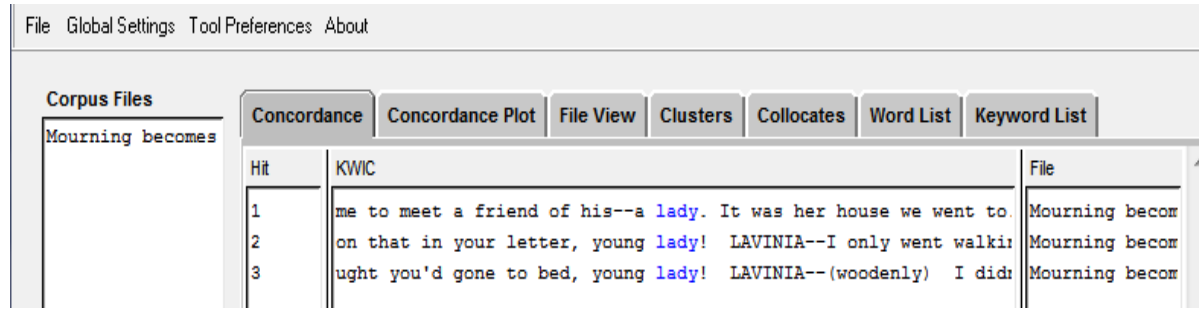

However, terms of endearment are not used between the father and his daughter. This does not deny that fact that Lavinia loves her father so excessively that she suffers from Electra complex.
2018

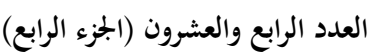
()
مجلة كلية التربية- جامعة عين شمس35 
It may pinpoint her psychological introvert nature as introduced in the Greek myth. She has emotional restrictions that hinder the expression of her emotions. However, she refers to him by the term 'Father' 57 times in the Homecoming, compared to only 9 times for the term 'mother'.

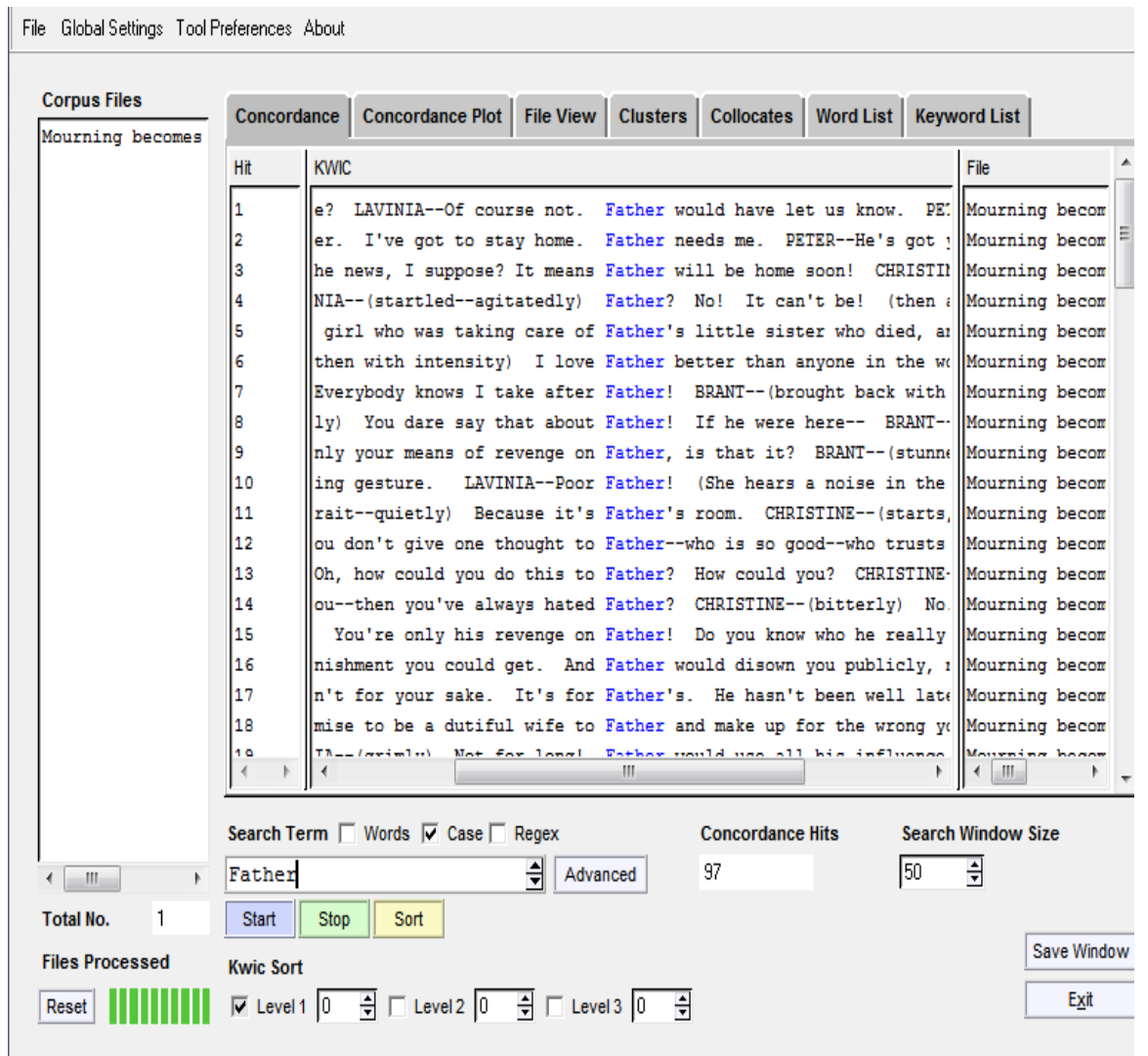

\subsection{Collocation}

O'Neill made use of motifs based on Greek myth that may be traced throughout the whole trilogy. The most 


\section{Nagwa Younis}

important of these is the concept of fate and destiny. The lexical item 'fate' occurs 29 times as 'type', and 40 times as 'token'. With this considerably frequent occurrence, it collocates with negative semantic prosodies of words like: 'tactlessly, forced, breaks'.

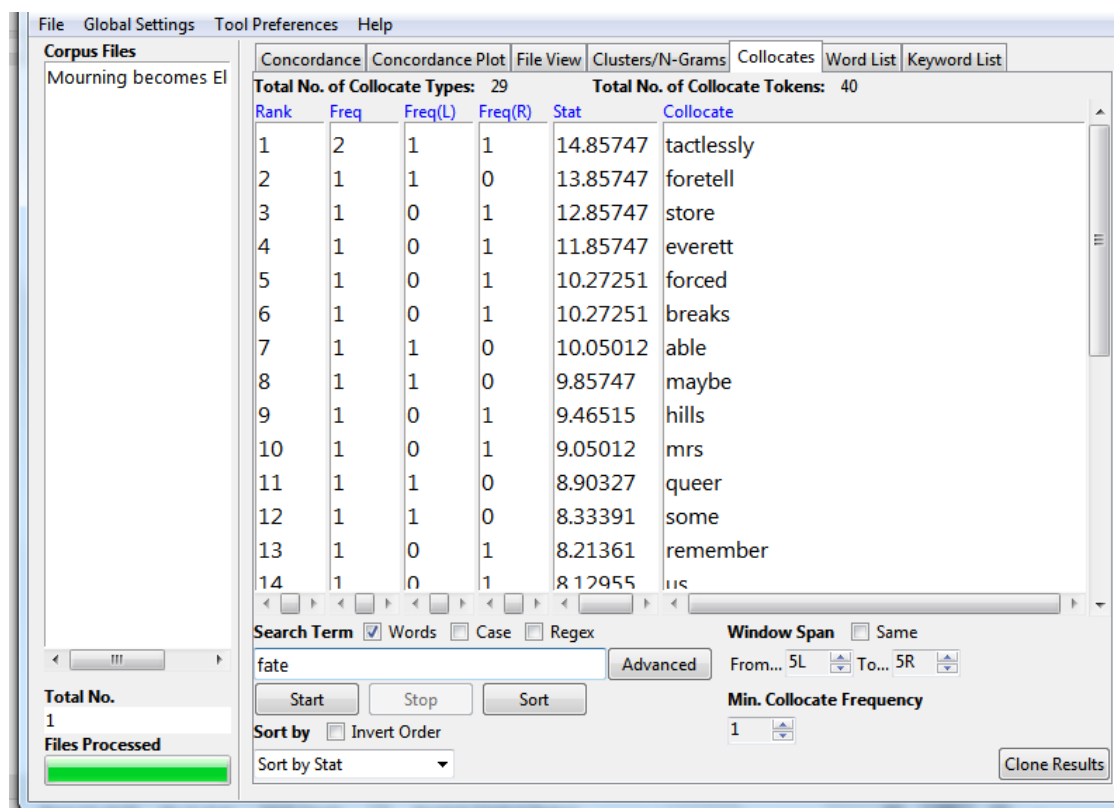

The lexical item 'destiny' is lower in frequency than 'fate' (14 types, 20 tokens), however it collocates, not only with negative semantic prosodies, but with family members (mother and Mannon) as well. The lexical item 'death' as a pivotal concept in both the Electra myth and the trilogy has the highest frequency (275 type, 670 token). The collocates concomitant with the word 'death' are very revealing. 

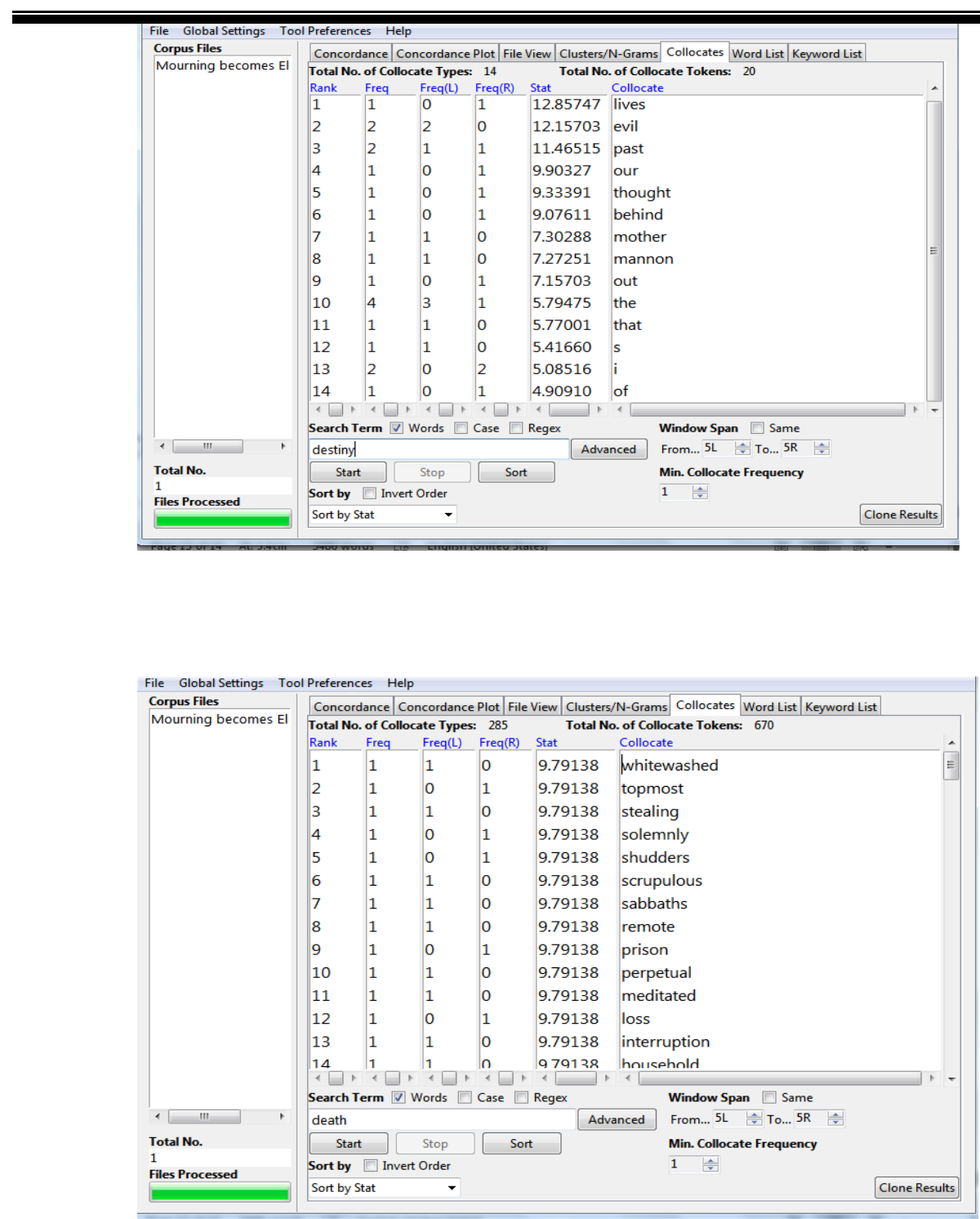

\section{3.a. Mother-daughter interaction}

Lavinia, or Electra in the Greek Myth, has a very tense relation with her mother. Thus, as the collocates of the word daughter show, no words of positive connotations are
2018
العدد الرابع والعشرون (الجزء الرابع)
()
مجلة كلية التربية- جامعة عين شمس38 
used. Since a word is known by the company it keeps, as the Neo-Firthians postulate, the word daughter has gained negative semantic prosody from collocates such as 'widow' and 'confronting'.

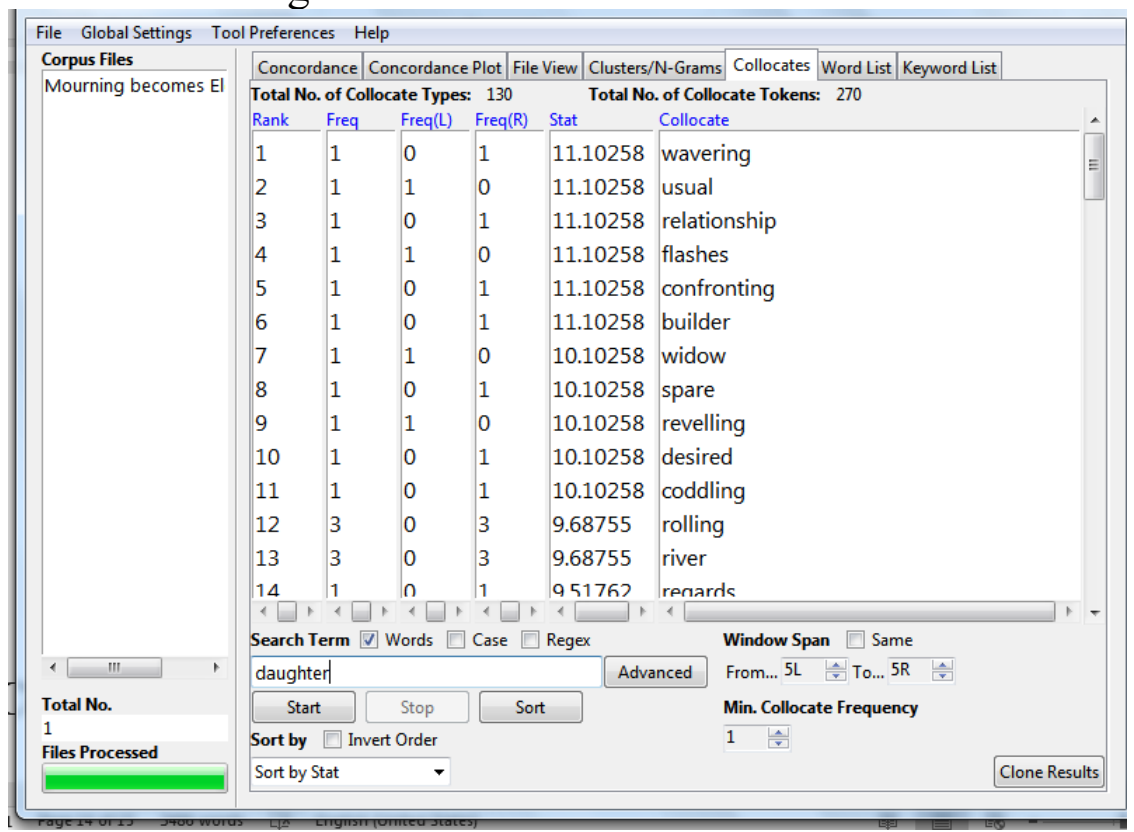

\section{3.b. Husband-wife interaction}

Though it lacks any endearment or feelings of love, the relationship between Ezra Mannon and his wife Christine is characterized by cunning and cheating on her part, as a feature of the Electra-myth. The collocates of the word 'husband' reflect this through the negative semantic prosodies pertained to it. 
At the Discourse-Myth interface: A Corpus-based Analysis of Mourning Becomes Electra

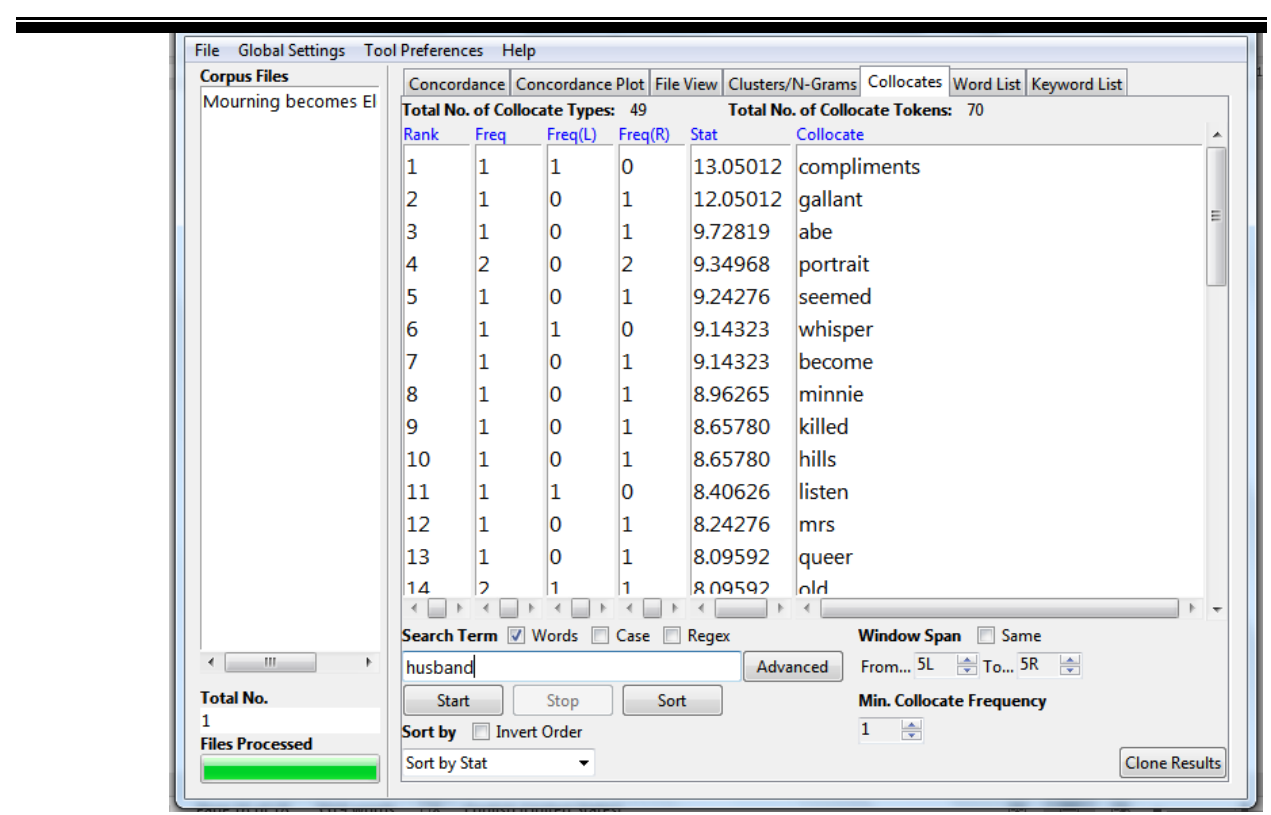

\section{3.c. Mother-son interaction}

Indicative as it seems to be, the collocates of the word 'mother' characterize the relationship between Orin and his mother Christine.

$$
\text { مجلة كلية التربية- جامعة عين شمس40 }
$$




\section{Nagwa Younis}

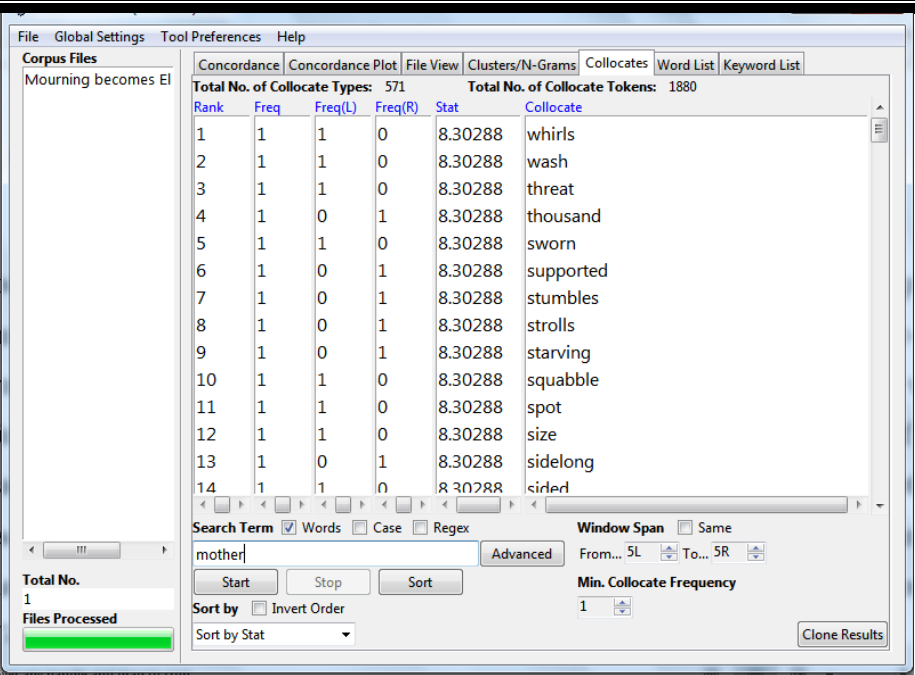

As for the collocates of the word 'son', they almost all express dependency and cowardice: 'servant', 'infantry, 'cowardly', etc.

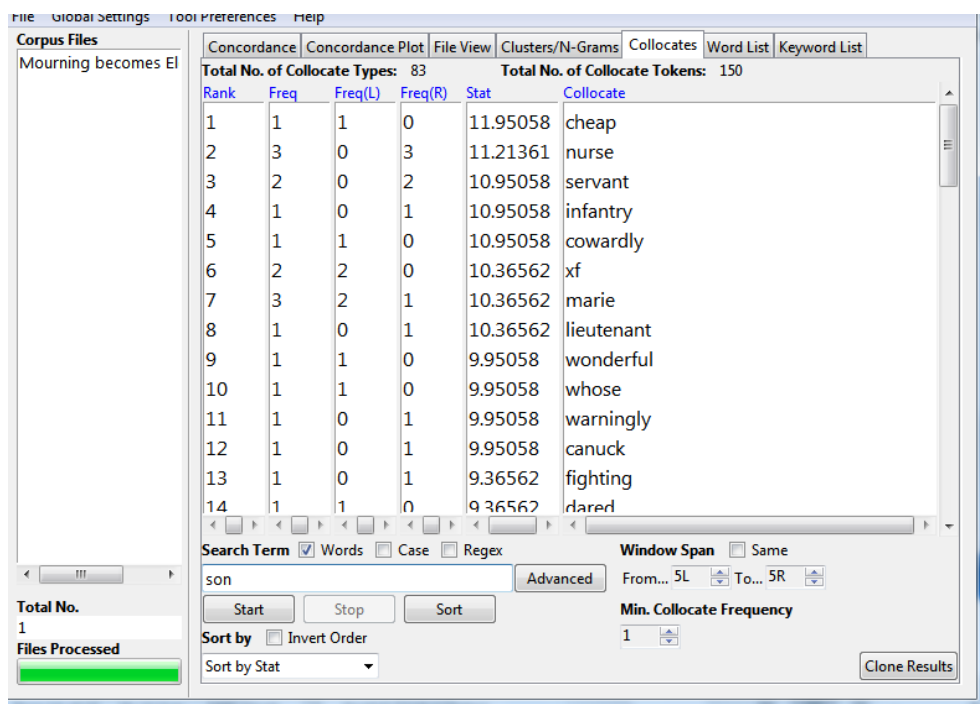

\section{3.d. father-daughter interaction}

As miserable as the life and death of Mannon, the collocates of the lexical item 'father' are gloomy and
2018
العدد الرابع والعشرون (الجزء الرابع) 81
()
مجلة كلية التربية- جامعة عين شمس41 
At the Discourse-Myth interface: A Corpus-based Analysis of Mourning

Becomes Electra

clumsy. Words like 'woundedly', 'starving', 'single' give negative connotations as results show. O’Neill condenses the connotational representations of the Electra Myth through the shades of meaning surrounding the word 'father'.

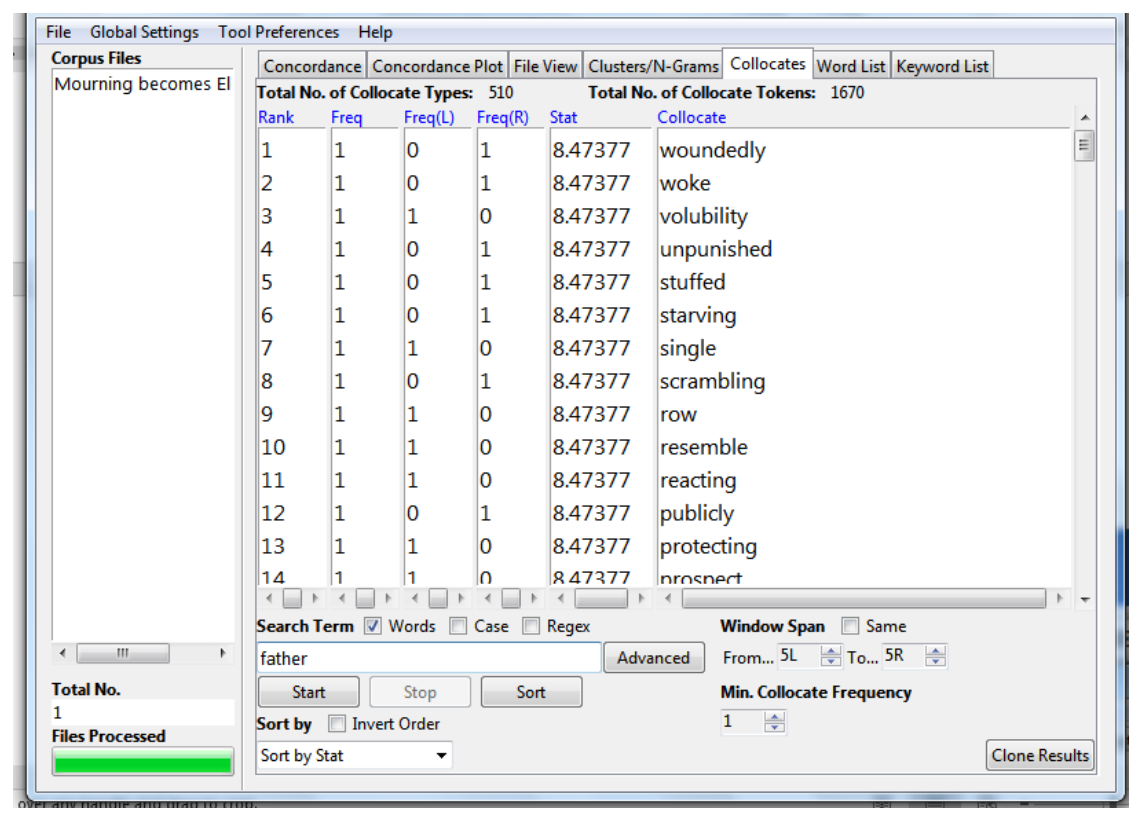

\section{Findings and Conclusion}

Through a corpus-based analysis, the language of O'Neill's trilogy Mourning Becomes Electra has been scrutinized with a view to depicting how what is mythical is correlated with what is real through discursive practices. Keyness, or Keyword in Context (KWIC) has been examined against the reference corpus COCA (Corpus of Contemporary American) to highlight the most significantly used words in the play. This reveals the major thematic lexical items that bring the Electra-myth into reality. Frequency is another technique used to shed light on the

$$
\begin{aligned}
& \text { العدد الرابع والعشرون (الجزء الرابع) } 2018 \\
& \text { مجلة كلية التربية- جامعة عين شمس42 }
\end{aligned}
$$


discursive preferences suggested by the playwright to perpetuate the shades of meaning concomitant with the Electra-myth. The third technique is collocation or the habitual co-occurrence of lexical items within the text. Negative semantic prosodies coloured all four family interactions in the trilogy as they mirror the tragic incidents of the myth.

The analysis of mother-daughter interaction, for instance, gives a glimpse of the tense relationship between Lavinia and her mother, Christine Mannon, that is characterized by mutual hatred, disrespect and enmity. This untypical mother-daughter relationship has its atypical father-daughter/ mother-son counterparts that portray a tragic atmosphere shadowed by the gloomy scent of the Electra-myth. Discursive practices serve as linguistic realizations that bridge the gap between the mythical and the real.

This paper is an attempt to trace the linguistic features that construct the interplay between discourse and myth. Both qualitative and quantitative methods of corpus analysis are used as tools for analysis. The techniques suggested are keyword in context (KWIC), frequency and collocation. They have been applied to four types of interaction identified in the play: a) mother-daughter interaction; b) husband-wife interaction; c) mother-son interaction, and d) father-daughter interaction. These techniques have been useful tools for the linguistic interpretation of the play, i.e. how the talks of the characters in the play are true reflections of the way(s) they feel towards one another. Consequently, the analysis eventually sheds light on O'Neill's view of the nature of human relationships as treated dramatically throughout the play and as mirroring the Greek myth.

In an attempt to answer the research questions, the discursive practices that give the spell of 'myth' are examined in Mourning Becomes Electra. These are manifested in the configuration of linguistic units that both formally and functionally bring to mind the ancient Greek Electra myth. Characters interactions are linguistically portrayed to serve both the mythical and the real.
2018

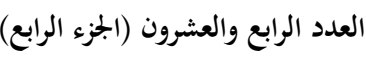
()
جملة كلية التربية- جامعة عين شمس43 
At the Discourse-Myth interface: A Corpus-based Analysis of Mourning Becomes Electra

Though the theme of the trilogy is plotted under the hood of the mythical, the real is crystal clear in the modern realistic stream of events. Corpus-based analysis has been used to reveal the discourse-myth interface.

Intertwining linguistic analysis with cultural studies on the discursive level serves a multiplicity of implications. Trapping heaven and earth in a cage of form, to quote McLeish, is exactly what writers do. As linguists, we carry the burden of scrutinizing this cage to see what is kept beyond it. Linguistic tools are adapted to depict how the universe is wrapped through the writer's viewpoint to reshape reality.

العدد الرابع والعشرون (الجزء الرابع) 2018 


\section{References}

Anthony, L. (2018) AntConc, version 3.5.7. Waseda University, Japan. www.laurenceanthony.net/software/antconc/

Baker, P., \& McEnery, A. (Eds.). (2015). Corpora and discourse studies: Integrating discourse and Corpora. London, UK: Palgrave Macmillan.

Baker, P. (2008). Useful methodological synergy? Combining critical discourse analysis and corpus linguistics to examine discourses of refugees and asylum seekers in the UK press.

Barthes, R. (1972). "Mythologies”, New York: Hill and Wang,

Biber, D. (2011). Corpus Linguistics and the Study of Literature. Back to Future? Scientific Study of Literature, 1(1), 15-23.

Biber, D., Conrad, S., \& Reppen, R. (1998). Corpus linguistics: Investigating language structure and use. Cambridge: Cambridge University Press.

Cassirer, E. (1946) Language and Myth. Dover Publications.

Culpeper, J. (2009). Keyness: Words, parts-of-speech and semantic categories in the character talk of Shakespeare's Romeo and Juliet. International Journal of Corpus Linguistics, 14(1), 2959.

Eagleton, T. (1991). Ideology: An introduction. London: Verso.

Flowerdew, L. (2012) Corpora and Language Education. Basingstoke: Palgrave Macmillan.

Hunston, S, and Francis, G. (2000). Pattern grammar. A corpusdriven approach to the lexical grammar of English.: John Benjamins: Amsterdam and Philadelphia.

Levi-Straus, C. (1955) The Structural Study of Myth. The Journal of American Folklore Vol. 68, No. 270, Myth: A Symposium (Oct. - Dec., 1955), pp. 428-444.

Lincoln, B. (1999). Theorizing myth. Chicago: University of Chicago Press.

العدد الرابع والعشرون (الجزء الرابع) 2018

مجلة كلية التربية- جامعة عين شمس45 
At the Discourse-Myth interface: A Corpus-based Analysis of Mourning Becomes Electra

Louw, B. (1993). Irony in the text or insincerity in the writer? The diagnostic potential of semantic prosodies. In M. Baker, G. Francis, \& E. Tognini-Bonelli (Eds.), Text and technology: In honour of John Sinclair (pp. 157-176). Amsterdam: John Benjamins.

Müller, M (1885) Lectures on the Science of Language, vol. 1, London.

Murphy, B. (2010) Corpus and Sociolinguistics: Investigating age and gender in female talk. John Benjamin Publishing Company: Amsterdam.

Romero-Trillo, J. (ed.) (2015) Yearbook of Corpus Linguistics and Pragmatics

Current Approaches to Discourse and Translation Studies. Springer International Publishing: Switzerland.

Partington, A. (1998). Patterns and meanings: Using corpora for English language research and teaching. Philadelphia, PA: John Benjamins.

Scott, M. \& Tribble, C. (2006) Textual Patterns: Key Words and Corpus Analysis in Language Education. Philadelphia: John Benjamins.

Sinclair, J. (1991). Corpus, concordance, collocation. Oxford, UK: Oxford University Press.

Sinclair, J. (1996). The search for units of meaning. TEXTUS: English Studies in Italy, 9(1), 75-106.

Sinclair, J. (2004). Trust the Text: Language, Corpus and Discourse. London: Routledge.

Stubbs, M. (1996). Text and Corpus Linguistics. Oxford: Blackwell. 